\title{
Applying DNA marker to detect R-genes of nematode-resistance among potato varieties and interspecies hybrids
}

\author{
E. P. Shanina \\ Ural Scientific Research Veterinary Institute \\ Federal State Budgetary Scientific Institution \\ "Ural Federal Agrarian Scientific Research Centre", \\ Ural Branch of the Russian Academy of Science \\ Glavnaya Street, 21, Istok settlement, \\ Yekaterinburg, Russia, 620061 \\ E-mail: shanina08@yandex.ru
}

\author{
L.S. Sergeeva \\ Ural Scientific Research Veterinary Institute \\ Federal State Budgetary Scientific Institution \\ "Ural Federal Agrarian Scientific Research Centre", \\ Ural Branch of the Russian Academy of Science \\ Glavnaya Street, 21, Istok settlement, \\ shanina08@yandex.ru
}

\begin{abstract}
The varieties and interspecies hybrids of potato selected on the basis of Ural Scientific Research Veterinary Institute Federal State Budgetary Scientific Institution "Ural Federal Agrarian Scientific Research Centre, Ural Branch of the Russian Academy of Science" (Ural national research institute of agriculture - the branch of USRVI FSBSI "UFASRC, UB of the RAS") have been studied with the application of three DNA markers. Based on the results of the study the data on the genes resistant (collection) to the golden cyst nematode was obtained on the basis of two markers and a pale cyst nematode on the basis of one marker with the purpose to select the specified parameters. The use of DNA markers with the high accuracy enabled to identify interspecies hybrids with R-genes. The group of potato variations with resistance to the nematodes under research according to three markers has been distinguished. The high saturation of the collection with the genes from $S$. andigenum to marker TG-689 from Hlgene to golden potato nematode which are found among $82 \%$ of the collection specimens was stated. The potato variations classified as slightly affected (up to 5 cysts per a root) according to the Russian scale are characterized by containing the genes of resistance to golden potato nematode in the genotype, which enables to equate these variations with the resistant ones.
\end{abstract}

Keywords—potato, variation, source material, markers, R-gene, resistance

\section{INTRODUCTION}

The efficiency of selecting any cropper greatly depends on the degree of its genetics exploration degree. Potato as the subject of research is much more sophisticated than the majority of agricultural plants. Variations of a cultivated potato are autotetraploid heterozygotes whose genotype is supported by the vegetative reproduction. In case of hybridization it is characterized by complex disjoining stipulated by heterozygosity of seed parents and tetrasomy inheritance of certain characteristics. In contrast to diploids having two possibilities of allele status (homozygotes and heterozygotes), each dominating allele of potato can be represented in two doses (simplex, duplex, triplex, quadruplex). The multiple allelism leads to obtaining an extremely varied, confusion offspring. With regards to the mentioned peculiarities of potato its genetic research are majorly restricted to studying the dominant character inheriting. These characteristics are determined by the key genes of persistence to diseases and pests and some other qualitative characteristics as well. They are mainly coded by dominant genes, which are capable of producing an effect even in complex states. Most of them are introgressed into the variations of the wild potato species. The task of a crop breeder is to combine as many genes of such kind in one variation as possible with the objective to obtain the variations with the complex resistance to pests and diseases. Development and implementation of the MAS-marker assisted selection (marker aided selection) technique being the selection with the help of DNA markers has massively simplified the solution of this problem [1]

The data concerning the presence of definite agricultural genes enables to optimize the selection of seed parents, predict the probability of selecting the plantlets with the desirable set of attributes among the hybrids obtained by crossover. In the meantime, the assessment of a great amount of plantlets with regards to DNA markers is considered to be irrational due to the fact that most of them will be rejected in the process of testing tuber generations due to their low productivity, unsatisfactory markers of the morphological characteristic of plants (long creeping stems, bush sprawling, etc.) and tuber (improper shape, deep potato eyes, etc.) It is suggested to apply MAS at the stage of competitive variety trial while the obtained results (concerning the presence or absence of certain economically valuable genes) enable to give a more detailed characteristic of the future potato variation. However, the application of DNA markers in potato selection is of the preliminary importance when assessing and creating a source material [1].

The development of the variations with high genetic resistance to pathogenic agents is connected with a set of complexities. One of them is tetraploid forms hybridization, which results in providing big variation and complex disjoining of the studied factors in hybrid flocks. Eventually, it aggravates the selection of genotypes with the desired attributes or a combination of attributes due to the necessity to research large amounts of hybrid plantlets. 
A lot of methods are rather laborious, time-consuming (take the whole vegetation period) and are not accurate enough. The method of molecule marking of the selection-valuable genes (R-genes) resistant to pests and diseases is the solution of the problem mentioned above and increases in the potato selection efficiency $[2,3,4]$.

Studying DNA markers of potato genes is connected with involving genetic material of wild potato forms (carrying the genes resistant to pathogenic agents) into the selection process $[5,6,7,8]$. The hybrids carrying the genes resistant to bacterial rot, golden cyst nematode, pale cyst nematode, etc. transmitted from the wild potato forms grown in the Alps were involved and effectively created for the further selection $[8,9,10,11]$.

All known nematode resistant potato variations are of interspecific origin while the genome S. tuberosum ssp. tuberosum L. does not have the genes resistant to potato cyst forming nematodes of the following types: Globodera rostochiensis and Globodera pallida. Selectionists have been searching for the source of resistance since 1950s. Nowadays, the variations resistant to cyst forming nematodes have been obtained. Such types as $S$. andigenum, S. vernei. S. sparsipilum, $S$. Spegazzinii have been used to create them. Two more types S. gourlay, S. oplocense were involved in creating the advanced breeding material [12]. Thus, despite the obtained results in applying wild potato forms it is necessary to undertake the PCR analysis with the purpose to determine the presence of genes resistant to cyst forming nematodes in selecting. Application of DNA markers interlinked by genes enables to speed up the selection process and increase its efficiency.

Nowadays, two DNA markers resistant to cyst forming nematodes have become widely used. Gpa marker 2-2 is linked to the gene resistant to Globodera pallida (gene Gpa2) [13]. Markers Gro 1-4-1 and TG689 contain the gene resistant to Globodera rostochiensis (gene $\mathrm{HI}$ and Gro 1-4 correspondingly) $[14,15]$. According to the findings of Belorussian scientists, marker Gro 1-4-1 was present in 7 variations out of 70 analyzed variations [16]. According to another source of information, the mentioned marker was found in 12 variations out of 78 analyzed variations [1]. Thus, the frequency of this marker is rather small, which makes the selection material carrying this gene more valuable.

The modern methods of studying plant genome reveal even greater opportunities for selecting crops. Contemporary literature review has indicated that the application of the molecular biology methods including PCR analysis greatly empowers crop breeders. The use of molecular markers systems enables to study the DNA polymorphism, elicit genetic relations, define the genes of agronomic character, which has become a relevant direction in selecting different croppers including potato.

\section{MATERIALS AND METHODS}

The research has been conducted in selection technological research center majoring in potato of Federal State Budgetary Scientific Institution "Ural Federal Agrarian Scientific Research Centre, Ural Branch of the Russian Academy of Science" (Ural national research institute of agriculture - the branch of USRVI FSBSI "UFASRC, UB of the RAS") under the state task on the topic № 0772-2014-0003 “Study and keep the potato source material for gaining and applying donors and genetic sources in selection oriented at the specified characteristics". The paper presents the use of variations and interspecies hybrids of Ural selection.

A set of reagents produced by the company "Syntol" was used for vegetational DNA extraction. A standard protocol for DNA selection has been used. The most productive markers TG689, Gro 1-4-1, Gpa 2-2 have been searched in literature sources with the purpose to be used in analyzing hybrid specimens (Table 1).

TABLE 1 APPLIED DNA MARKERS OF GENES RESISTANT TO POTATO PESTS

\begin{tabular}{|l|l|l|l|}
\hline Gene & Marker & \multicolumn{1}{|c|}{ Primers (5' -3') } & Source \\
\hline & & F - & Brodie, \\
T1 & $\begin{array}{l}\text { TG } \\
689_{141}\end{array}$ & $\begin{array}{l}\text { R- } \\
\text { CAAACTCTTGGTTATAGCCTAT }\end{array}$ & 1999 \\
\hline $\begin{array}{l}\text { Gro } \\
1-4\end{array}$ & $\begin{array}{l}\text { Gro 1- } \\
4-1_{602}\end{array}$ & $\begin{array}{l}\text { F - AAGCCACAACTCTACTGGAG } \\
\text { R - GATATAGTACGTAATCATGCC }\end{array}$ & $\begin{array}{l}\text { Asano, } \\
2012\end{array}$ \\
\hline $\begin{array}{l}\text { Gpa } \\
2\end{array}$ & $\begin{array}{l}\text { Gpa 2- } \\
2452\end{array}$ & F - GCACTTAGAGACTCATTCCA & $\begin{array}{l}\text { Mori, } \\
2011\end{array}$ \\
\hline
\end{tabular}

Two markers, TG 689141 and Gro 1-4-1602, have been used to detect the gene resistance to golden cyst potato nematode. Reaction for each marker was set independently under the identical conditions of amplification.

A reaction mixture for PCR with the primers with the volume equal to $12 \mathrm{mql}$ contained $2 \mathrm{mql}$ of DNA, $1 \mathrm{mql}$ of a standard buffer for Tag- polymerase, $0.3 \mathrm{mql} \mathrm{dNTP}, 0.4 \mathrm{mql}$ $\mathrm{MgCl} 2,0.25 \mathrm{mql}$ of each primer, $0.1 \mathrm{mql}$ of Tag- polymerase, $8.3 \mathrm{mql} \mathrm{H} 2 \mathrm{O}$.

Amplification was conducted in the following mode: 940C - min.; 35 cycles: $920 \mathrm{C}-45$ sec., $600 \mathrm{C}-45$ sec., $720 \mathrm{C}-1$ $\min ; 720 \mathrm{C}-10 \mathrm{~min}$.

Subsequent to the results of amplification and further electrophoresis in $1.5 \%$ agarose gel, all the outcomes are displayed on a computer screen in the form of a table. Table 2 shows that the fluorescence of the obtained PCR product is on the level of 140-145 bps (according to the scale of the applied marker lengths up to $1500 \mathrm{bps}$ ), which is equivalent of the length of marker fluorescence TG689. The fluorescence of the positive control sample is also within the range of 140-145 bps.

When compiling the protocol of gene resistance to Gro 1-4 and composing a reaction mixture the amount of DNA samples was increased by $1 \mathrm{bps}$, while the fluorescence was less intensive than earlier when the quality of the isolated DNA was checked. The protocol of the reaction mixture is equal to $13 \mathrm{mql}$ with primers and DNA of the sample: 3 mqlDNA, $1 \mathrm{bps}$ of a standard buffer for Tag- polymerase, $0.3 \mathrm{dNTP}, 0.4 \mathrm{bps} \mathrm{MgCl} 2$, $0.25 \mathrm{bps}$ of each primer, $0.1 \mathrm{mql}$ of Tag- polymerase, $8.3 \mathrm{mql}$ $\mathrm{H} 2 \mathrm{O}$. Amplification was conducted in the following mode: 920C -45 sec., $600 \mathrm{C}-45 \mathrm{sec} ., 720 \mathrm{C}-1 \mathrm{~min} ; 720 \mathrm{C}-10 \mathrm{~min}$. 
TABLE 2 THE PRESENCE OF GENE RESISTANT TO H1 OF A DNA MARKER TG689 IN HYBRID POTATO SPECIMENS

\begin{tabular}{|l|l|l|l|l|l|l|l|l|l|l|l|l|l|l|l|}
\hline & & & & & & & & \\
\hline
\end{tabular}

TABLE 3 PRESENCE OF RESISTANCE GENE GRO 1-4 OF DNA MARKER GRO 1-4-1 IN POTATO SAMPLES

\begin{tabular}{|c|c|c|c|c|c|c|c|c|c|c|c|c|c|c|c|c|c|c|}
\hline \multicolumn{19}{|c|}{ The presence of resistance gene Gro 1-4 in potato } \\
\hline 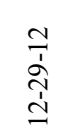 & & & 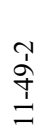 & $\begin{array}{l}\bar{j} \\
\hat{\jmath} \\
\grave{3}\end{array}$ & & & 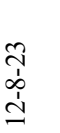 & $\begin{array}{l}\mathcal{I} \\
\text { o } \\
\dot{I} \\
\text { İ }\end{array}$ & & & 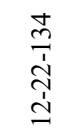 & & & 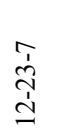 & $\begin{array}{l}0 \\
\stackrel{\oplus}{N} \\
\text { ปn }\end{array}$ & & & 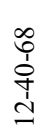 \\
\hline 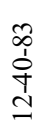 & $\frac{I}{ \pm}$ & 竎 & $\begin{array}{l}\stackrel{J}{7} \\
\underset{+}{+} \\
\stackrel{\sim}{\simeq}\end{array}$ & 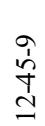 & 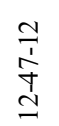 & $\stackrel{I}{I}$ & 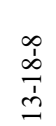 & 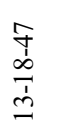 & 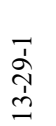 & $\begin{array}{l}\frac{n}{1} \\
\vec{f} \\
\stackrel{2}{2}\end{array}$ & $\frac{\tilde{m}}{\vec{f}}$ & 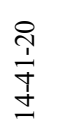 & $\stackrel{\overbrace{}}{\stackrel{1}{=}}$ & 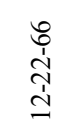 & 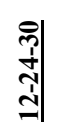 & $\begin{array}{l}\text { İ } \\
\text { ஸे }\end{array}$ & بـ & \\
\hline
\end{tabular}

The outcomes of amplification and electrophoresis in $1.5 \%$ agarose gel have led to distinguishing 13 samples with distinctive fluorescence at the length of 600-605 bps. The fluorescence of a positive control sample was at the same level, which corresponds to the fluorescence of the desired DNA paragraph of gene Gro 1-4 (Table 3).

The presence of the pale nematode requires selecting the hybrids resistant to this pest right now. We have chosen the marker Gpa 2-2 with the gene Gpa 2.

The reaction mixture for PCR with $12 \mathrm{mql}$ of primers contained: $2 \mathrm{mql}$ DNA, $1 \mathrm{mql}$ of a standard buffer for agpolymerase, $0.3 \mathrm{mql} \mathrm{dNTP,} 0.4 \mathrm{mql} \mathrm{MgCl} 2,0.25 \mathrm{mql}$ of each marker, $0.1 \mathrm{mql}$ of ag- polymerase, $8.3 \mathrm{mql} \mathrm{H}_{2} \mathrm{O}$. The mode of amplification was as follows: $940 \mathrm{C}-10 \mathrm{~min}$; 5 cycles: $940 \mathrm{C}-$ $30 \mathrm{sec}$, $680 \mathrm{C}-30 \mathrm{sec}$, $720 \mathrm{C}-1.5 \mathrm{~min}$; 35 cycles: $940 \mathrm{C}-30$ sec., $580 \mathrm{C}-30 \mathrm{sec}$., $720 \mathrm{C}-1.5 \mathrm{~min} ; 720 \mathrm{C}-5 \mathrm{~min}$.

\section{RESULTS AND DISCUSSIONS}

The outcomes of the potato genotypes molecular screening for the gene $\mathrm{Hl}$ resistant to golden cyst potato nematode have shown that 144 variations and interspecies hybrid out of 176 were distinguished with the marker TG $689_{141}$, which makes $82 \%$. The correlation between the pathotype Rol resistance obtained via the traditional infective method and the presence of the corresponding DNA marker among the analyzed samples is equal to $93 \%$. It proves a high diagnostic value of the given marker.
Twelve groups with similar origin out of 36 have samples with the gene $H 1$. Predominantly, the groups formed on the basis of genetic origin had 2-4 samples (Table 4).

TABLE 4 PRESENCE OF DNA MARKER TG $689_{141}$ RESISTANT TO GOLDEN CYST POTATO NEMATODE OF RO1 PATHOTYPE IN THE STUDIED SAMPLES WITH SIMILAR GENETIC ORIGIN

\begin{tabular}{|c|c|c|c|}
\hline $\begin{array}{c}\text { Origin } \\
\text { number }\end{array}$ & $\begin{array}{c}\text { Number of } \\
\text { studied samples }\end{array}$ & $\begin{array}{c}\text { Number of } \\
\text { samples with } \\
\text { gene } \boldsymbol{H 1}\end{array}$ & $\begin{array}{c}\text { Number of } \\
\text { samples } \\
\text { without gene } \\
\boldsymbol{H} \mathbf{1}\end{array}$ \\
\hline $05-15$ & 2 & 2 & - \\
\hline $08-41$ & 2 & 2 & - \\
\hline $08-54$ & 2 & 2 & - \\
\hline $10-22$ & 3 & 3 & - \\
\hline $10-44$ & 2 & 1 & 1 \\
\hline $12-14$ & 4 & 3 & - \\
\hline $12-22$ & 12 & 12 & 1 \\
\hline $12-29$ & 4 & 3 & 3 \\
\hline $12-47$ & 3 & - & - \\
\hline $13-18$ & 4 & 4 & 2 \\
\hline $13-41$ & 7 & 5 & - \\
\hline $14-19$ & 2 & 1 & \\
\hline $14-53$ & 3 & 3 & \\
\hline & & & \\
\hline
\end{tabular}

Consequently, the application of marker TG $689_{141}$ for determining the resistance to golden cyst potato nematode in the process of selection enables not only to reduce the sampling material bulk but also to increase its quality.

Moreover, TG $689_{141}$ is present in the potato variations classified as slightly affected by golden cyst potato nematode (according to laboratory findings), such as Baron and Gorniak, 
which are classified (according to selective breeding results record) as irresistible to this type of pathogenic agents (Table 5). The laboratory evaluation criteria according to Russian scale of resistance to golden cyst potato nematode are rather strict and do not assume the presence of even one cyst, there are from 1 to 5 cysts in the category "slightly affected"; however, the slightly affected potato variations are classified by the selective breeding results record as the irresistible ones.

It is necessary to refer the laboratory findings to the new direction of marker-associated selection (MAS), which is the selection with DNA markers, whose application enables to evaluate the material with regards to a genotype. It is much more efficient to identify a certain gene in a genotype with the help of MAS than to do it on the basis of phenotype, especially in case of the markers to dominant genes of resistance $R$-genes.

TABLE 5 PRESENCE OF PCR MARKERS IN POTATO VARIATIONS AND CORRESPONDENCE TO THE LABORATORY FINDINGS WITH REGARDS TO RO1

\begin{tabular}{|c|c|c|c|c|c|}
\hline \multirow[b]{2}{*}{$\begin{array}{l}\text { Variety, } \\
\text { hybrid }\end{array}$} & \multicolumn{3}{|c|}{ Markers } & \multirow[b]{2}{*}{$\begin{array}{l}\text { Laboratory tests } \\
\text { for Ro1 }\end{array}$} & \multirow[b]{2}{*}{ Record } \\
\hline & $\begin{array}{c}T G \\
689_{141}\end{array}$ & $\begin{array}{c}\text { Gro } \\
1-4- \\
1_{602}\end{array}$ & $\begin{array}{c}G p a \\
2-2452\end{array}$ & & \\
\hline Baron & + & + & + & slightly effected & rv \\
\hline Gorniak & + & + & 0 & slightly effected & rv \\
\hline Kamensky & 0 & + & 0 & irresistant & rv \\
\hline Irbitsky & + & + & 0 & resistant & $\mathrm{rn}$ \\
\hline Amur & 0 & + & 0 & irresistant & rv \\
\hline Bravo & + & + & 0 & resistant & $\mathrm{rn}$ \\
\hline Luks & + & + & 0 & resistant & $\mathrm{rn}$ \\
\hline Start & + & + & 0 & resistant & $\mathrm{rn}$ \\
\hline Mishka & + & 0 & 0 & resistant & $\mathrm{rn}$ \\
\hline $12-47-19$ & + & 0 & 0 & slightly effected & - \\
\hline $12-22-66$ & + & 0 & + & slightly effected & - \\
\hline $12-29-19$ & + & 0 & 0 & slightly effected & - \\
\hline $12-17-12$ & + & 0 & 0 & slightly effected & - \\
\hline $13-43-2$ & + & 0 & + & slightly effected & - \\
\hline
\end{tabular}

Note: $\mathrm{rv}$ is irresistant to golden cyst potato nematode (Ro1); rn is resistant to golden cyst potato

The high saturation of the collection with genes from $S$. andigenum is accounted for the long period applying this variation in selection and a rather easy introgression of its genes to a cultivated potato due to evolutionary similarity (according to modern classification $S$. andigenum is a subspecies of $S$. tuberosum) concerning their ploidy and effective ploidy [17].

Marker Gro 1-4-1602 was used to detect gene Gro 1-4 resistant to golden potato nematode. As a result of analyzing 30 potato variations and interspecies hybrid 13 samples, which makes $43 \%$, are diagnosed with possessing the given marker.

According to literary sources the presence of the mentioned marker is low, which makes the breeding material bearing this gene to be rather valuable. Selection of gene Gro 1-4 carriers and inserting them into the schemes of selection on the resistance to cyst forming nematode is no less important than the use of the sources of gene $H 1$, which is more frequent in breeding material. Moreover, the distinguished sources with Gro 1-4 are classified as resistant to pathotypes Ro2 and Ro5. It is believed that this gene was introgressed into breeding material of wild species $S$. spegazzinii [17].

196 samples were studied on the presence of gene Gpa 2. Positive results were obtained in 28 variations and hybrids, which makes $14 \%$ of all analysis. The studied samples composed of 36 groups formed on the basis of relationship were analyzed as well. The gene Gpa 2 was present in $40 \%$ of the analyzed genotypes in the genotype of group 12-29 (Table 6).

More detailed work with hybrid generations and selection of test forms for assessing their allele status was done with the objective to provide a more accurate evaluation of seed parents. However, the obtained results enable to conclude that the highest selection value of seed parents was achieved in the variations: Baron, Luks, Mishka and interspecies hybrids: 0515-7, 08-20-2, 12-22-66. DNA marker Gpa 2-2452 of the gene resistant to pale nematode Globodera pallida is of rather frequent occurrence while the geographic spread of pale potato nematode over the territory of the Russian Federation is rather small. Although, search for and mobilization of genetic sources with regards to resistance is a very relevant objective taking into account the fast spread of dangerous pathogen to the territory of the Russian Federation.

TABLE 6 PRESENCE OF DNA MARKER GPA 2-2 452 RESISTANT TO PALE NEMATODE GLOBODERA PALLIDA IN THE STUDIED SAMPLES WITH SIMILAR GENETIC ORIGIN

\begin{tabular}{|c|c|c|c|}
\hline $\begin{array}{c}\text { Origin } \\
\text { number }\end{array}$ & $\begin{array}{c}\text { Number of } \\
\text { studied } \\
\text { samples }\end{array}$ & $\begin{array}{c}\text { Number of } \\
\text { samples with } \\
\text { gene Gpa 2 }\end{array}$ & $\begin{array}{c}\text { Number of } \\
\text { samples } \\
\text { without gene } \\
\text { Gpa 2 }\end{array}$ \\
\hline $05-15$ & 3 & - & 3 \\
\hline $08-41$ & 2 & - & 2 \\
\hline $08-54$ & 2 & - & 2 \\
\hline $10-22$ & 3 & - & 3 \\
\hline $10-44$ & 3 & 1 & 2 \\
\hline $10-54$ & 2 & 1 & 1 \\
\hline $12-14$ & 4 & 1 & 3 \\
\hline $12-22$ & 8 & 1 & 7 \\
\hline $12-29$ & 5 & 3 & 2 \\
\hline $12-47$ & 4 & 2 & 2 \\
\hline $13-18$ & 3 & 1 & 8 \\
\hline $13-41$ & 8 & - & 2 \\
\hline $14-32$ & 2 & - & 3 \\
\hline $14-53$ & 3 & - & \\
\hline
\end{tabular}

\section{CONCLUSION}

The outcomes of molecule screening of the potato variations and interspecies hybrids selected on the basis of Ural Scientific Research Veterinary Institute Federal State Budgetary Scientific Institution "Ural Federal Agrarian Scientific Research Centre, Ural Branch of the Russian Academy of Science" (Ural national research institute of agriculture - the branch of USRVI FSBSI "UFASRC, UB of the RAS") have enabled to distinguish the variation Baron and 12 variations of the following types: 10-44-5, 10-54-9, 12-14-18, 12-29-13, 1229-14, 12-41-7, 13-18-8, 13-18-50, 13-35-13, 14-32-6, 14-519, 14-59-17 with high selection value. The genotype of the mentioned potato variations and interspecies hybrids contain all three analyzed markers of the genes resistant to various nematodes. Namely, the resistance to golden cyst potato nematode of Globodera rostochiensis type on two markers: TG $689_{141}$ introgressed into cultivated potato resistant to $S$. andigenum and Gro 1-4-1 602 resistant to the wild species $S$. spegazzinii, as well as a pale nematode of Globodera pallida type on the marker Gpa 2-2452. 


\section{References}

[1] "Genetic basis of plant breeding. In 4 t. Genetic bases of plant breeding", A.V. Kilchevsky, L.V. Khotyleva, Eds. Minsk: Belarus. Navuka, 2014, vol. 4, pp. 243-275.

[2] A.P. Ermishin., E.V. Voronkova, A.V. Savchuk et al, "Evaluation of potato source material for breeding for resistance to diseases and pests using specific PCR markers", Method. Recommendations, Minsk: Law and Economics, 2010, 60 p.

[3] A. Barone, "Molecular marker assisted selection for potato breeding", Am. J. Potato Res, 2004, vol. 81, pp. 111-117.

[4] C. Gebhardt, J.P.T. Valkonen, "Organization of genes controlling disease resistance in the potato genome", Annu. Rev. Phytopathol., 2001, vol. 39, pp. 79-102.

[5] J.G. Hawkes, M.T. Jackson, "Taxonomic and evolutionary implications of the Endosperm Balance Number hypothesis in potatoes", Theor. Appl. Genet, 1992, vol. 84, pp. 180-185.

[6] S. Jansky, "Breeding for Disease Resistance in Potato",.J. Janick, Eds. Plant Breeding Reviews, vol. 19, Oxford, UK: John Wiley \& Sons, Inc, 2000.

[7] R. Machida-Hirano, "Diversity of potato genetic resources", Breed. Sci., vol. 65, 2015, pp. 26-40.

[8] K.N. Watanabe, S.J. Peloquin , "The occurrence and frequency of $2 n$ pollen in $2 \mathrm{x}, 4 \mathrm{x}$, and $6 \mathrm{x}$ wild, tuber-bearing Solanum species from Mexico, and Central and South America",. Theor. Appl. Genet., vol. 82, 1991, pp. 621-626.

[9] D. Carputo, L. Frusciante, S.J. Peloquin , "The role of $2 \mathrm{n}$ gametes and Endosperm Balance Number in the origin and evolution of polyplopids in the tuber-bearing Solanums", Genetics, vol. 163, 2003, pp. 287-294.

[10] R. Ortiz, S.J. Peloquin, "Use of 24-chromosome potatoes (diploids and dihaploids) for genetical analysis, J.E. Bradshaw, G.R. Mackay, Eds.,
Potato Genetics, Wallingford, UK: CAB International, 1994, pp. 133154.

[11] K.N. Watanabe, R. Ortiz, J.A. Watanabe, "Breeding Potential and Transmission of Traits in $4 \mathrm{x}-2 \mathrm{x}$ Crosses", in Genetic Improvement of Solanaceous Crops, vol. 2, Chapter 4, M.K. Razdan, A.K. Mattoo, Eds., USA: Science Publishers Inc., 2005, pp. 83-99.

[12] O.V. Makhanko, G.A. Yakovleva, N.I. Drobot, R.A. Gorbanev, N.I. Naumovich, "Assessment of potato source material for the presence of TG689, CP113 and GRO 1-4 markers of resistance to the golden potato nematode Globodera rostochiensis woll", Potato farming: a collection of scientific papers, 2012, vol. 20, pp. 70-84.

[13] K. Mori, Y. Sakamoto, N. Mukojima, S. Tamiya, T. Nakao, T. Ishii, • K. Hosaka, "Development of a multiplex PCR method for simultaneous detection of diagnostic DNA markers of five disease and pest resistance genes in potato", Euphytica, vol. 180, 2011, pp. 347-355.

[14] K. Asano, A. Kobayashi, S. Tsuda, M. Nishinaka, S. Tamiya, "DNA marker-assisted evaluation of potato genotypes for potential resistance to potato cyst nematode pathotypes not yet invading into Japan", Breeding Science, 2012,vol. 62, pp. 142-150.

[15] B.B. Brodie, K. Evans, J. Franco,. "Nematode parasites of potato", in Plant Parasitic Nematodes in Temperate Agriculture, K. Evans, D.L. Trugill, J.M. Webster, Eds.,.Wallingford: CAB International, 1988, pp. $87-132$.

[16] N.V. Pavlyuchuk et al, "Assessment of potato resistance to the golden potato nematode Globodera rostochiensis: methodical recommendations", Min-s of agricultural and prod. of the Republic of Belarus, State Scientific Institution "Institute of Genetics and Cytology of the National Academy of Sciences of Belarus", RUE "Institute for Plant Protection", Minsk: IOOO "Law and Economics", 2011, p. 43.

[17] I.M. Yashin, et. al, "Guidelines for breeding nematode-resistant potato varieties", Moscow: Russian Agricultural Academy, VNIIKH, 2010, p 26. 